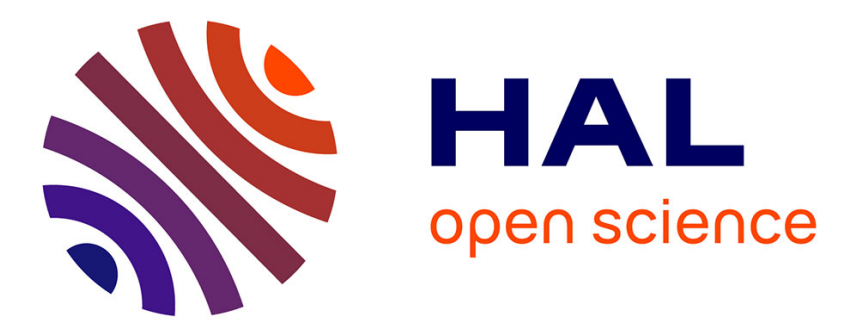

\title{
Strategy to produce highly loaded alumina supported CoMo-S catalyst for straight run gas oil hydrodesulfurization
}

A Miño, Christine Lancelot, P., Blanchard, Carole Lamonier, Loic Rouleau, Magalie Roy-Auberger, S. Royer, E Payen

\section{To cite this version:}

A Miño, Christine Lancelot, P., Blanchard, Carole Lamonier, Loic Rouleau, et al.. Strategy to produce highly loaded alumina supported CoMo-S catalyst for straight run gas oil hydrodesulfurization. Applied Catalysis A : General, 2017, 530, pp.145-153. 10.1016/j.apcata.2016.11.027 . hal-01488030

\section{HAL Id: hal-01488030 https://hal.science/hal-01488030}

Submitted on 13 Mar 2017

HAL is a multi-disciplinary open access archive for the deposit and dissemination of scientific research documents, whether they are published or not. The documents may come from teaching and research institutions in France or abroad, or from public or private research centers.
L'archive ouverte pluridisciplinaire HAL, est destinée au dépôt et à la diffusion de documents scientifiques de niveau recherche, publiés ou non, émanant des établissements d'enseignement et de recherche français ou étrangers, des laboratoires publics ou privés. 


\section{Strategy to produce highly loaded alumina supported CoMo-S catalyst}

\section{for straight run gas oil hydrodesulfurization.}

A. Miño, ${ }^{a}$ C. Lancelot, ${ }^{\mathrm{a}, *}$ P. Blanchard, ${ }^{\mathrm{a}}$ C. Lamonier, ${ }^{\mathrm{a}}$ L. Rouleau, ${ }^{\mathrm{b}}$ M. Roy-Auberger, ${ }^{\mathrm{b}}$ S. Royer, ${ }^{\mathrm{a}, *}$ and E. Payen ${ }^{\mathrm{a}}$

${ }^{a}$ Université Lille, CNRS, Centrale Lille, ENSCL, Univ. Artois, UMR 8181 - UCCS - Unité de Catalyse et de Chimie du Solide, F-59000 Lille, France.

b IFP Energies Nouvelles, Rond-Point de l’Echangeur de Solaize, BP3, 69360 Solaize (France).

* Email. christine.lancelot@univ-lille1.fr; Tel. +33-3-20-43-43-87.

* Email. sebastien.royer@univ-lille1.fr; Tel.+33-3-20-43-69-54 


\section{Abstract}

A simple postmodification synthesis is proposed to produce large pore volume alumina, with addition of a porogen during the peptization step, which is an industrial process preceding alumina shaping. By adjusting the synthesis parameters, obtained alumina present improved textural properties compared to conventional ones: specific surface areas between 380 à 430 $\mathrm{m}^{2} \cdot \mathrm{g}^{-1}$, large pore diameters between 12 and $20 \mathrm{~nm}$ and consequently large pore volumes. This allowed to prepare highly loaded catalysts, at a density of $4 \mathrm{at}_{\mathrm{Mo}} \cdot \mathrm{nm}^{-2}$, without the formation of undesirable bulk molybdenum-cobalt oxide species despite the high molybdenum content. Catalysts performance were evaluated in thiophene HDS, where the activity varied by a factor 1.5. The most performant solid of the series was then tested in the HDS of a straight run gas oil under industrial conditions: it showed significantly improved activity compared to that of a catalyst prepared from a commercial alumina with the same molybdenum density, with a temperature gain of $17^{\circ} \mathrm{C}$ at $100 \mathrm{ppm}$ residual sulfur. Moreover, the catalyst activity remained stable after one week of testing. This work thus evidences that the development of alumina supports with enhanced textural properties is an efficient way to improve the performance of HDS CoMo catalysts.

Keywords: mesoporous alumina, hydrotreatment, mesostructuration, SRGO

\section{Introduction}

Due to the continuous evolution in regulations concerning the sulfur content in transportation fuels, actually limited to $10 \mathrm{ppm}$ in European countries [1], a significant improvement of the hydrodesulfurization (HDS) process of petroleum feedstocks is needed. The development of more performant catalytic materials is an effective solution to limit significant evolution of the process conditions. Conventional HDS catalysts are composed of nanometric $\mathrm{MoS}_{2}$ crystallites promoted by cobalt atoms and 
dispersed on porous supports [2-4], obtained by sulfidation of an oxide precursor [5]. The morphostructural properties of the support are important parameters: large surface area is beneficial to the active phase dispersion, while pore volume conditions metal loadings that can be achieved [6-7]. Large pore diameter is also researched for a better diffusion of reactants during reaction [8], an important issue if we consider that heavier petroleum cuts are going to be treated for further incorporation in transportation fuels. Consequently, the development of mesostructured oxide synthesis offered new perspectives for catalyst preparation [9-10], as these supports exhibit particularly high surface area with tunable mesopore size. Since the first reports on the synthesis of silica based mesoporous molecular sieves, from the M-41S family [9] and further from the SBA family [11-12], adaptation of mesotructuration methodologies to the synthesis of other oxides [13-17], including $\mathrm{Al}_{2} \mathrm{O}_{3}$ [18-21], was proposed. Mesoporous alumina syntheses are based on precursor hydrolysis or precipitation in the presence of structure directing agent (anionic, cationic or neutral) [22-23]. For silica, the pore size can be adjusted by a judicious choice of the templating agent and/or by the use of a swelling agent in addition to the template $[9,12,24-27]$. Such control is however more difficult for alumina. Hydrolysis conditions (temperature, $\mathrm{pH}$, agitation), composition of the gel/precipitate (water, structuring agent, solvent), hydrothermal and maturation conditions are however keys to control pore structure properties [21,28]. In addition, periodic mesostructure over alumina can be difficult to maintain during template extraction [29] and wormhole-like porosity is often obtained [19-23]. Evaporation Induced Self Assembly route is however reported as efficient to produce Organized Mesostructured Alumina (OMA) [30,31], with some flexibility on the inorganic network composition [32,33] and pore structure characteristics [33-35]. With pore sizes 
in the mesopore range and high surface areas, templated alumina are good candidates as support for catalytic applications.

While mesostructured silica-based materials were extensively studied as HDS catalyst supports [36-46], the use of non-siliceous mesostructured oxides for HDS reactions is, in contrast, scarce. Cejka et al. [47] and Kaluza et al. [48] prepared wormhole-like mesoporous alumina and due to support characteristics, well-dispersed molybdenum species were observed even at $\mathrm{MoO}_{3}$ loading as high as $30 \mathrm{wt} \%$. Catalysts having up to two times higher activity than a commercial one (containing 15 wt\% $\mathrm{MoO}_{3}$ ) were obtained. Hicks et al. [49] also studied the preparation of mesostructured alumina supported CoMo catalysts. Limited catalytic performances were reported due to loss in surface area and pore volume of the support under sulfiding treatment and under HDS reaction conditions. Such lack in stability over mesoporous alumina was also observed by Bejenaru et al. [50]. Despite limited stability, some of the catalysts displayed high catalytic performances (in the HDS of thiophene), especially those obtained over alumina exhibiting large mesopores and fine fibrillar morphology. HDS performances were also dependent on the nature of molybdate species present in oxidic form on the support. Low activity catalysts initially presented monomolybdate species whereas polymolybdate species were identified before sulfidation over high activity samples. Other authors also related the observed better performance of $\mathrm{Co}(\mathrm{Ni}) \mathrm{Mo}$ catalysts supported on mesostructured alumina to higher reducibility of molybdenum over such supports [51-53].

The reported results showed the potential of mesostructured alumina as support for HDS catalysts, despite the absence of organized pore network for most of the catalysts. We then propose herein the use of a porosity modification method to design supports with improved textural properties. The approach presents the advantage to be simple and adaptable to 
conventional alumina: the process is established after boehmite precipitation during peptization, porosity of alumina being modified by addition of a porogen to generate large and adjustable porosity [54,55]. Peptization step is indeed required prior to material shaping in catalyst support industry. This step consists in reducing the size of the boehmite agglomerates by adsorption of protons on the surface of the particles causing electrostatic repulsion. Peptization by the mean of various acids leads to metastable sols or homogeneous pastes that are used to prepare shaped supports, obtained after extrusion, drying and calcination [56,57]. In this work, we studied the influence of the different synthesis parameters on the textural properties of alumina, which were further used as supports for highly loaded CoMo HDS catalysts.

The solids were characterized and their performance evaluated in thiophene HDS. The most efficient catalyst of the series was then tested in Straight Run Gasoil (SRGO) HDS and its desulfurization ability was compared to that of a catalyst prepared on a commercial alumina with the same molybdenum atom surface density (dMo).

\section{Experimental methods}

\subsection{Support synthesis}

Large porosity alumina supports were prepared using a modified two step synthesis approach [54]. The first step consisted in the precipitation of aluminum nitrate $\left(\mathrm{Al}\left(\mathrm{NO}_{3}\right), 9 \mathrm{H}_{2} \mathrm{O}\right.$ Aldrich, $\left.>99 \%\right)$ by an ammoniac solution $\left(\mathrm{NH}_{3(\mathrm{aq})}, 25\right.$ wt\%), with a precipitation media composition of $1 \mathrm{Al}: 27.8 \mathrm{H}_{2} \mathrm{O}: 103.4 \mathrm{NH}_{3}$ solution (expressed in mol). The aluminum hydroxide precipitate was recovered by filtration and washed. Thereafter, the hydrate precipitate was dispersed in water and peptized with nitric acid 1 mol. $\mathrm{L}^{-1}$ at $80^{\circ} \mathrm{C}$ before maturation for $2 \mathrm{~h}$ at $60^{\circ} \mathrm{C}$. The porogen, the triblock copolymer Pluronic P123 (BASF, poly(ethyleneoxide)-block-poly(propyleneoxide)- 
block-poly(ethyleneoxide), $\mathrm{EO}_{20} \mathrm{PO}_{70} \mathrm{EO}_{20}$ ), was then added at the selected concentration and the mixture was maintained under stirring at ambient temperature for 12h. The molar composition was, depending on the quantity of peptizing and porogen agents, $1 \mathrm{Al}: 55.6 \mathrm{H}_{2} \mathrm{O}:$ x $\mathrm{P} 123(\mathrm{x}=0,0.011,0.022$ or 0.035$): \mathrm{y} \mathrm{HNO}_{3}(\mathrm{y}=0.8,1.3$, 1.8 or 3.1). Alumina support was obtained after evaporation of the solvent at $120^{\circ} \mathrm{C}$ and calcination of the resulting powder under air at $550^{\circ} \mathrm{C}$ during $4 \mathrm{~h}$ (temperature increase rate of $1{ }^{\circ} \mathrm{C} \cdot \mathrm{min}^{-1}$ ). Alumina supports were named $\mathrm{Al}-\mathrm{xP} 123-\mathrm{yHNO} \mathrm{H}_{3}$, where $\mathrm{x}$ was the porogen to alumina molar ratio (P123/Al) and y the peptizing agent to alumina molar ratio $\left(\mathrm{HNO}_{3} / \mathrm{Al}\right)$.

\subsection{Catalyst synthesis}

CoMo oxidic precursors were prepared by incipient wetness impregnation of the alumina supports, using an aqueous solution obtained by dissolution of $\left[\mathrm{Co}_{2} \mathrm{Mo}_{10} \mathrm{O}_{38} \mathrm{H}_{4}\right] \mathrm{Co}_{3}$ (cobalt salt of $\mathrm{Co}_{2} \mathrm{Mo}_{10} \mathrm{O}_{38} \mathrm{H}_{4}{ }^{6-}$ heteropolyanion, noted hereafter $\mathrm{Co}_{2} \mathrm{Mo}_{10}$ ). This compound was prepared according to the protocol described in ref [58]. Concentration of the solution was adjusted to achieve, with the selected volume of solution, a molybdenum density of $4 \mathrm{at}_{\mathrm{Mo}} \mathrm{nm}^{-2}$ in the final catalyst. The Co/Mo molar ratio in the catalyst was imposed by the stoichiometry of the $\left[\mathrm{Co}_{2} \mathrm{Mo}_{10} \mathrm{O}_{38} \mathrm{H}_{4}\right] \mathrm{Co}_{3}$ entity $(\mathrm{Co} / \mathrm{Mo}=0.5)$. After impregnation and maturation under wet atmosphere conditions for $2 \mathrm{~h}$ (to ensure a satisfying precursor infiltration in the support porosity), the solids were dried $12 \mathrm{~h}$ at $100^{\circ} \mathrm{C}$ and calcined at $500^{\circ} \mathrm{C}$ under oxygen.

\subsection{Material characterization}

$\mathrm{N}_{2}$ adsorption-desorption isotherms were recorded at $-196^{\circ} \mathrm{C}$ using an automated ASAP2010 instrument from MICROMERITICS. A known mass of sample (around

$0.200 \mathrm{~g}$ ) was heated at $350^{\circ} \mathrm{C}$ under vacuum for $3 \mathrm{~h}$. Specific surface areas (SSA) were 
calculated from the linear part of the Brunauer-Emmett-Teller curve. Pore size distributions were obtained by applying the Barrett-Joyner-Halenda (B.J.H.) equation to the desorption branch of the isotherm and total pore volume was estimated from the $\mathrm{N}_{2}$ uptake value at $\mathrm{P} / \mathrm{P}_{0}=0.98$.

Powder X-ray diffraction patterns were recorded on a SIEMENS D5000 diffractometer equipped with a $\mathrm{CuK} \alpha$ anticathode $\left(\lambda=1.5406 \AA\right.$ ), for $2 \theta$ between $10^{\circ}$ and $80^{\circ}$, using a $0.1^{\circ}$ step with an integration time of $4 \mathrm{~s}$. Phase identification was carried out by comparison with the JCPDS database.

Co and Mo species present on the support were identified by Raman spectroscopy. Spectra of the oxidic precursors were recorded at room temperature, using a Raman microprobe Infinity instrument from Jobin-Yvon, equipped with a $\mathrm{N}_{2}$ cooled CCD detector. The exciting laser source was the $532 \mathrm{~nm}$ line of a Nd-YAG laser.

For X-ray photoelectron spectroscopy (XPS) analysis, samples were pressed on an indium foil attached to the sample holder and spectra were recorded using a VG ESCALAB 220 XL spectrometer equipped with a monochromatic AlK $\alpha(E=1486.6$ eV) X-ray source (without air exposure in the case of sulfided catalysts). The surface atomic ratios were calculated using the CASA software.

High resolution electron microscopy was performed on a TECNAI microscope (200kV) equipped with a $\mathrm{LaB}_{6}$ crystal.

\subsection{Catalytic activity}

Thiophene was selected for evaluation and comparison of the catalysts properties, since it is the simplest molecule representative of the aromatic sulfur compounds present in the hydrotreatment feeds. Reaction was performed at atmospheric pressure in a flow-type reactor packed with $0.200 \mathrm{~g}$ of catalyst. Before reaction, the oxidic precursor was heated at $400^{\circ} \mathrm{C}$ under atmospheric pressure for $2 \mathrm{~h}$ (temperature 
increase rate of $\left.6^{\circ} \mathrm{C} \mathrm{min}^{-1}\right)$, under a flow of 10 vol. $\% \mathrm{H}_{2} \mathrm{~S}$ in $\mathrm{H}_{2}\left(60 \mathrm{~mL} \mathrm{~min}{ }^{-1}\right)$. The reactor was then cooled to the reaction temperature $\left(300^{\circ} \mathrm{C}\right)$. Thiophene (previously purified by two successive vacuum distillations) was introduced in the reactor at a constant partial pressure of $6.65 \mathrm{kPa}$ in a flow of hydrogen (total flow rate $=10$ $\mathrm{mL} \cdot \mathrm{min}^{-1}$ ). Reactants and products (butane, but-1-ene, trans-but-2-ene, cis-but-2-ene) were analysed using a gas chromatograph equipped with a flame ionization detector and a Plot-alumina column. The conversion was calculated taking into account the relative response factor of each compound.

In order to evaluate the potential of the solids in the HDS of real feedstock and in conditions close to the industrial ones, selected catalysts were tested on a Straight Run Gas Oil (SRGO) containing $1 \mathrm{wt} \% \mathrm{~S}$, in a high pressure up-flow microreactor. 10 $\mathrm{mL}$ of catalyst pellets (with selected granulometry, between 0.3 and $0.5 \mathrm{~mm}$ ) were diluted with $15 \mathrm{~mL}$ of carborundum $(0.25 \mathrm{~mm})$, before being loaded in the isothermal zone of the reactor. The catalysts were sulfided using a mixture of dimethyldisulfide (DMDS) and SRGO (2 wt\% DMDS + SRGO) and $\mathrm{H}_{2}$. After sulfidation, the feed was switched to the test feed (same SRGO than for sulfidation step), and the operating conditions stabilized (pressure $=35$ bar, $\mathrm{H}_{2} /$ oil $=250 \mathrm{NL} / \mathrm{L}, \mathrm{LHSV}=2 \mathrm{~h}^{-1}$ ). During each run, the temperature was changed in the sequence $350-360-370^{\circ} \mathrm{C}$. Two hydrotreated product samples were collected at each temperature after stabilization for 15 h. $\mathrm{H}_{2} \mathrm{~S}$ dissolved in the hydrotreated product oil was removed by stripping with nitrogen gas after sample collection. The total sulfur contents in treated feed samples were measured using an Antek 9000S sulfur analyzer (Ultra-Violet fluorescence). After one week of testing, the temperature was returned to $350^{\circ} \mathrm{C}$ to evaluate the stability of the system.

\section{Results and discussion}




\subsection{Survey of synthesis parameters allowing alumina texture control}

As presented in the experimental section, alumina supports were prepared using a simple two steps synthesis approach, consisting in precipitation followed by a peptization step with an acidic solution containing P123 porogen. Among the different ways to adjust porosity, the first one is to vary the amount of porogen added. Alumina were thus prepared by maintaining constant the conditions of precipitation and the $\mathrm{pH}$ of peptization step and varying the amount of porogen (Table 1).

Table 1. Effect of the amount of porogen on textural properties of alumina calcined at $550^{\circ} \mathrm{C}$.

\begin{tabular}{|c|c|c|c|c|}
\hline Sample & $\begin{array}{c}\mathrm{n}(\mathrm{P} 123) \\
/ \mathrm{mol}\end{array}$ & $\begin{array}{c}\mathrm{S}_{\mathrm{BET}} \\
/ \mathrm{m}^{2} \cdot \mathrm{g}^{-1}\end{array}$ & $\begin{array}{c}\mathrm{V}_{\mathrm{p}} \\
/ \mathrm{cm}^{3} \cdot \mathrm{g}^{-1}\end{array}$ & $\begin{array}{c}\mathrm{D}_{\mathrm{p}} \\
/ \mathrm{nm}\end{array}$ \\
\hline $\mathrm{Al}^{-0 \mathrm{P} 123-0 \mathrm{HNO}_{3}}$ & 0.000 & 293 & 0.30 & 3.8 \\
\hline $\mathrm{Al}-\mathrm{nP} 123-0.8 \mathrm{HNO}_{3}$ & 0.011 & 381 & 1.26 & 11.9 \\
& 0.022 & 411 & 1.63 & 12.9 \\
& 0.035 & 391 & 1.98 & 13.9 \\
\hline
\end{tabular}

The diffractograms of the three samples prepared with different P123 contents (Figure SI 1) confirmed the presence of a well crystallized $\gamma$-alumina phase whatever the P123 content (JCPDS No. 010-0425). The amount of porogen has no visible effect on the crystalline structure of the final solid, in the range of P123/Al ratio studied, with no significant changes in width and intensity of the reflections.

The $\mathrm{N}_{2}$ adsorption-desorption isotherms obtained for the precipitated alumina and for the three modified alumina supports are presented in Figure 1. All modified samples display isotherms of type IV, with parallel adsorption and desorption branches (and H1 type hysteresis). For the precipitated alumina without porogen addition, while isotherm is of type IV, the hysteresis is of $\mathrm{H} 2$ type, characteristic of the presence of 
slit-shaped pores. The pore size distribution of the precipitated alumina is narrow, centered at $3.8 \mathrm{~nm}$ (Table 1). Larger pore sizes between 12 and $14 \mathrm{~nm}$, increasing with the porogen content, are measured for the modified alumina (Table 1). As can be awaited from the pore size evolution, the pore volume also increases with the P123 content (Figure 1, Table 1), to reach $2 \mathrm{~cm}^{3} \cdot \mathrm{g}^{-1}$.

The porosity generated in the modified alumina occurs through the random rearrangement of elementary crystallites of alumina, with formation of pores not displaying regular shape and size, as can be concluded from the absence of small angle reflection on diffraction patterns over these materials (not shown). Consequently, the porogen role is to modify the aggregation of alumina particles, resulting in more airy aggregates with a decreased degree of connection between the elementary particles.

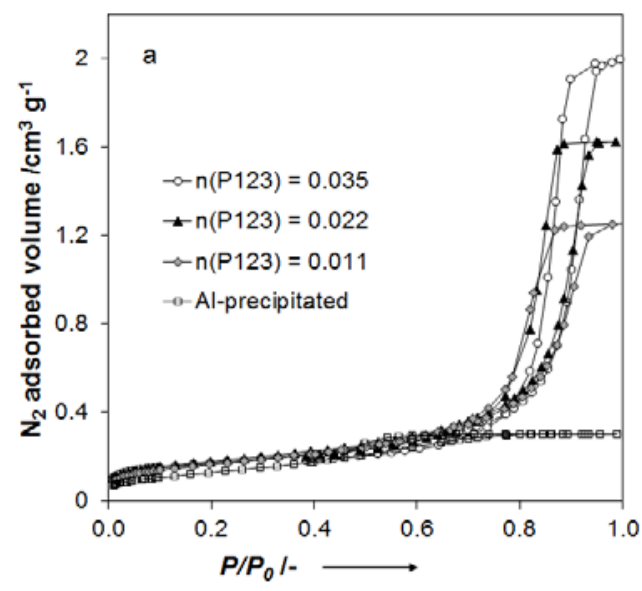

Figure 1. $\mathrm{N}_{2}$ adsorption-desorption isotherms of alumina prepared by PSM using different $\mathrm{P}(123)$ contents; $\mathrm{n}(\mathrm{P} 123)=0.011,0.022,0.035 \mathrm{~mol}$.

The second possible way to adjust material textural properties is the control of peptization conditions. Indeed, the role of the peptization step is to separate large agglomerates to obtain a stable suspension. Acidic conditions are applied to ensure the dissolution of a small fraction of the aluminum, their modification impacting dissolution rate and thus indirectly modifying the effect of the porogen on the 
rearrangement of the particles during drying step. Modified alumina supports were prepared at $\mathrm{HNO}_{3} / \mathrm{Al}$ molar ratio varying from 0.8 to 3.1 while maintaining constant the $\mathrm{P} 123 / \mathrm{Al}$ ratio equal to 0.022 . These values of $\mathrm{HNO}_{3} / \mathrm{Al}$ are higher than those classically used in a peptization process, but are comparable or slightly higher than values reported in studies developing comparable approaches for alumina porosity modification using porogen $\left(\left[\mathrm{H}^{+}\right] /\left[\mathrm{Al}^{3+}\right]=0.3-3.0[54]\right)$. However, preliminary experiments at lower ratio (below 0.8) indicated that the modification of porosity remained very limited with the precipitate synthesized in this study and that the 0.8 to 3.1 ratio is the range for which the largest modifications of porosities were achieved. For all the supports, after thermal treatment at $550^{\circ} \mathrm{C}, \mathrm{XRD}$ patterns are characteristic of the crystalline $\gamma$-alumina phase (not shown).
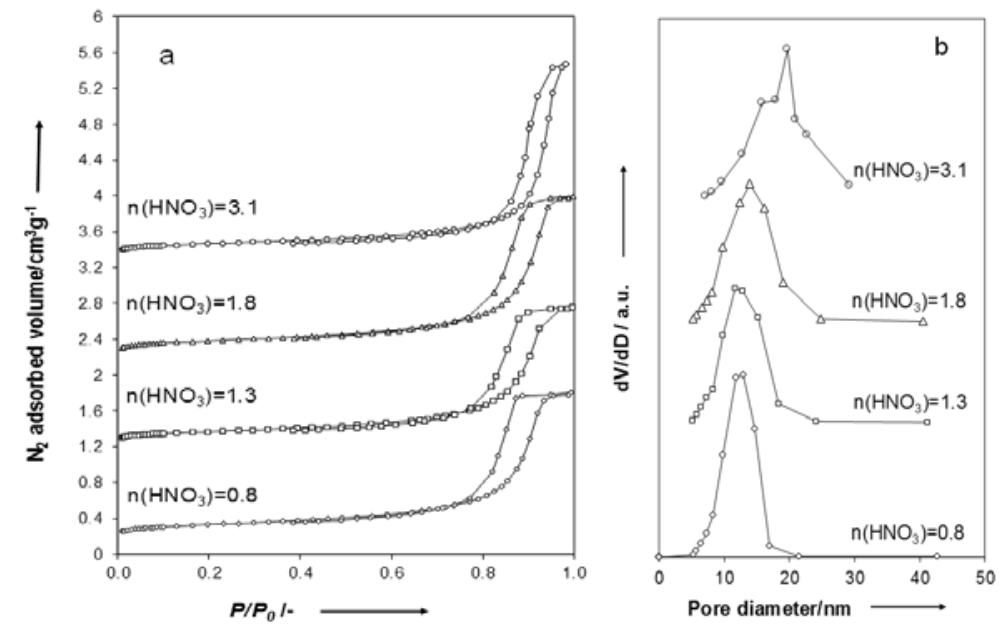

Figure 2. $\mathrm{N}_{2}$ adsorption-desorption isotherms (a) and BJH pore size distributions (b) obtained for alumina supports prepared under different peptization acidic conditions; $\mathrm{n}\left(\mathrm{HNO}_{3}\right)=0.8$, 1.3, 1.8, $3.1 \mathrm{~mol}$. Isotherms are shifted vertically by $1 \mathrm{~cm}^{3} \cdot \mathrm{g}^{-1}$ each to facilitate reading.

Table 2. Effect of peptization media acidity on the textural properties of the calcined alumina.

\begin{tabular}{|l|c|c|c|c|}
\hline Sample & $\mathrm{n}\left(\mathrm{HNO}_{3}\right)$ & $\mathrm{S}_{\mathrm{BET}}$ & $\mathrm{V}_{\mathrm{p}}$ & $\mathrm{D}_{\mathrm{p}}$ \\
\hline
\end{tabular}




\begin{tabular}{|c|c|c|c|c|}
\hline & $/ \mathrm{mol}$ & $/ \mathrm{m}^{2} \cdot \mathrm{g}^{-1}$ & $/ \mathrm{cm}^{3} \cdot \mathrm{g}^{-1}$ & $/ \mathrm{nm}$ \\
\hline Al-0P123-0HNO & 0 & 293 & 0.30 & 3.8 \\
\hline \multirow{2}{*}{ Al-0.022P123-nHNO } & 0.8 & 411 & 1.63 & 12.9 \\
& 1.3 & 386 & 1.54 & 11.7 \\
& 1.8 & 416 & 1.77 & 14.0 \\
& 3.1 & 378 & 2.12 & 19.7 \\
\hline
\end{tabular}

Materials prepared under different acidic conditions present $\mathrm{N}_{2}$ adsorptiondesorption isotherms of type IV with $\mathrm{H} 1$ hysteresis loop (Figure 2a). A progressive shift of the hysteresis loops towards higher $\mathrm{P} / \mathrm{P}_{0}$ values is observed with the increase in $\mathrm{HNO}_{3}$ content. The pore size distribution consequently shifts towards higher values with the increase in $\mathrm{HNO}_{3} / \mathrm{Al}$ molar ratio (Figure 2b). For the material prepared at the highest acidity, a mean pore size of $19.7 \mathrm{~nm}$ is measured. In parallel with the increase in mean pore size, a significant increase in pore volume is observed. While the precipitated alumina presents a pore volume as low as $0.30 \mathrm{~cm}^{3} \cdot \mathrm{g}^{-1}$, this value progressively increases to reach $2.12 \mathrm{~cm}^{3} \cdot \mathrm{g}^{-1}$ for Al-0.022P123-3.1 $\mathrm{HNO}_{3}$ (Table 2).

Despite the significant changes in pore size and pore volume with the acidity of the peptization media, the surface area remains around $400 \pm 20 \mathrm{~m}^{2} \cdot \mathrm{g}^{-1}$ whatever the $\mathrm{HNO}_{3}$ concentration used (Table 2). This suggests that the crystallite size of alumina is not significantly affected during the peptization step and that elementary particles will develop in all cases relatively constant surfaces after the modification step. Meanwhile, evolution in pore volume and pore size clearly shows changes in porogen efficiency with the acidity of the peptization medium. By playing on these two parameters of synthesis, it is then possible to stabilize large pore size and high pore volume in alumina materials, while maintaining specific surface areas around $400 \mathrm{~m}^{2} \cdot \mathrm{g}^{-1}$.

\subsection{Characterization of the CoMo-supported oxidic precursors.}


Three modified alumina were selected for catalysts preparation, together with a commercial alumina. Al-0.011P123-0.8HNO $\mathrm{HN}_{3}, \mathrm{Al}-0.035 \mathrm{P} 123-0.8 \mathrm{HNO}_{3}$ and $\mathrm{Al}-$ 0.022P123-3.1 $\mathrm{HNO}_{3}$, denoted respectively Al-A, Al-B and Al-C, were chosen to cover wide ranges of support pore volumes and pore sizes $\left(1.26,1.98\right.$ and $2.12 \mathrm{~cm}^{3} . \mathrm{g}^{-1}$ for pore volume; 11.9, 13.9 and $19.7 \mathrm{~nm}$ for pore size) while maintaining comparable specific surface areas (around $380 \mathrm{~m}^{2} \cdot \mathrm{g}^{-1}$ ). The commercial alumina, industrially used for HDS catalyst preparation, was denoted Al-P (for PURAL SB3) and calcined at $500^{\circ} \mathrm{C}$ prior to impregnation. The catalysts were named CoMoxAl-y where $\mathrm{x}$ is the molybdenum loading expressed in $\mathrm{MoO}_{3} \mathrm{wt} \%$ and y refers to the alumina support (A, $\mathrm{B}, \mathrm{C}$ and $\mathrm{P})$.

\subsubsection{Textural properties of the catalysts}

Upon impregnation, different behaviors were evidenced depending on the support:

- For the catalyst prepared using Al-A alumina, the isotherm shape remained of type IV, with minor modification in pore size distribution (Figure 3a, Table 3). The observed decrease in pore volume $\left(\Delta \mathrm{V}_{\mathrm{P}} \sim 20 \%\right)$ can be related to some pore blocking by the Co-Mo phases. However, differences in pore size and surface area with the support, when normalized by the weight gain issued from active phase deposition, remained moderate $(<20 \%)$. Such values are characteristic of a support not significantly impacted by the active phase impregnation, such as in the case of the commercial Pural support (Table 3).

- For catalysts prepared over the supports presenting higher pore size and pore volume (Al-B and Al-C), significant changes were observed upon impregnation. The isotherms remained of type IV (shown for CoMo25.4/Al-B, Figure 3b), with a significant decrease in $\mathrm{N}_{2}$ volume adsorbed. Hysteresis loops were observed to shift towards lower $\mathrm{P} / \mathrm{P}_{0}$ values. While the surface areas per gram of support remained 
almost constant upon catalyst preparation $\left(\Delta \mathrm{S}_{\mathrm{BET}}<20 \%\right)$, a significant decrease in pore size value was measured for both solids ( $\Delta \mathrm{D}_{\mathrm{P}} \sim 60 \%$ - Table 3$)$. This limited surface area decrease, combined to the significant decrease in pore size and volume, indicates a modification of the crystallites organization in the aggregates.
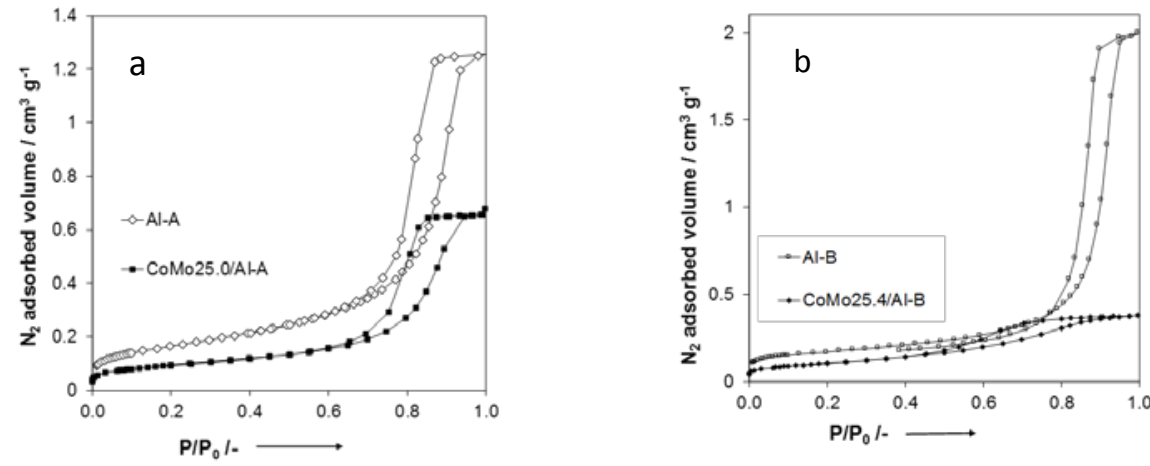

Figure 3. $\mathrm{N}_{2}$ adsorption-desorption isotherms of support $\mathrm{Al}-\mathrm{A}$ and catalyst CoMo25.0/Al-A (a), of support Al-B and catalyst CoMo25.4/Al-B (b).

Table 3. Textural properties of oxidic CoMo-containing catalysts.

\begin{tabular}{|c|c|c|c|c|c|c|}
\hline \multirow{2}{*}{ Sample } & \multicolumn{4}{|l|}{ Catalyst } & \multicolumn{3}{l|}{ Variations } \\
\cline { 2 - 7 } & $\begin{array}{c}\mathrm{S}_{\mathrm{BET}} \\
/ \mathrm{m}^{2} \cdot \mathrm{g}^{-1}\end{array}$ & $\begin{array}{c}\mathrm{V}_{\mathrm{p}} \\
\mathrm{cm}^{3} \cdot \mathrm{g}^{-1}\end{array}$ & $\begin{array}{c}\mathrm{D}_{\mathrm{p}} \\
/ \mathrm{nm}\end{array}$ & $\begin{array}{c}\mathrm{dMo}_{\text {real }} \\
/ \mathrm{at}^{-\mathrm{nm}^{-2}}\end{array}$ & $\begin{array}{c}\Delta \mathrm{S}_{\mathrm{BET}} \\
/ \%\end{array}$ & $\begin{array}{c}\Delta \mathrm{D}_{\mathrm{p}} \\
/ \%\end{array}$ \\
\hline CoMo25.0/Al-A & $219 / 320^{[\mathrm{a}]}$ & $0.66 / 0.96^{[\mathrm{a}]}$ & 11.1 & 4.8 & -16 & -7 \\
\hline CoMo25.4/Al-B & $244 / 359^{[\mathrm{a}]}$ & $0.37 / 0.55^{[\mathrm{a}]}$ & 5.2 & 4.4 & -8 & -64 \\
\hline CoMo24.8/Al-C & $211 / 307^{[\mathrm{a}]}$ & $0.65 / 0.95^{[\mathrm{a}]}$ & 7.2 & 4.9 & -19 & -63 \\
\hline CoMo14.1/Al-P & $161 / 196^{[\mathrm{a}]}$ & $0.37 / 0.45^{[\mathrm{a}]}$ & 7.3 & 4.0 & 9 & 0 \\
\hline
\end{tabular}

[a] Values corrected by removing the contribution of the weight gain consecutive to the introduction of the active phase (expressed per gram of support).

Several authors already reported important evolution of alumina support during impregnation process. In the case of mesoporous alumina, Hicks et al. [49] observed decreases between 24 and 59\% of the surface area and between 6 and $45 \%$ of the pore volume of the carrier after impregnation and calcination steps, depending on 
molybdenum content. However, the materials initially presented lower pore size and pore volume than the materials studied here. Authors attributed the decreases in surface area and pore volume to a thickening of the walls of the support porous structure and to pore filling. Limited hydrolytic stability of mesoporous alumina was also reported by Zhang et al. $[59,60]$. The porous network quickly lost its ordering when in contact with water, even at room temperature [19,61]. Alternative preparation methods to wet impregnation are reported in the literature to circumvent this issue: thermal spreading [62], impregnation by a solution of molybdenum dioxide diacetylacetonate in methanol [63], methanol assisted spreading of $\mathrm{MoO}_{3}$ [64].

In our work, pore collapse, due to a rearrangement of the elementary particles during aqueous impregnation step, was observed over alumina with the largest pore diameters. However, even in this case, the improved textural properties of the supports allowed increasing the loading in active phase up to $25 \mathrm{wt} \%$, while the same dMo corresponds to a value of $14 \mathrm{wt} \%$ on the Pural commercial support. Moreover, despite the textural modifications, the catalysts always retained adequate properties for their use in heterogeneous catalysis process.

\subsubsection{Raman analysis of oxidic supported CoMo phase}

Raman spectra of the CoMo oxidic precursors are presented in Figure 4. For all solids, a broad line at $952 \mathrm{~cm}^{-1}$ corresponding to well dispersed polymolybdate species on the support surface was identified [65,66]. Spectra recorded for CoMo25.4/Al-B and CoMo24.8/Al-C materials displayed additional sharp lines located at 690, 480 and 516 $\mathrm{cm}^{-1}$, revealing the presence of $\mathrm{Co}_{3} \mathrm{O}_{4}$ phase [67]. The use of $\mathrm{Co}_{2} \mathrm{Mo}_{10}$ as a precursor of CoMo phase, whatever the support nature (zirconium oxide, titanium oxide or $\gamma$ alumina), generally ensures the formation of well dispersed and easily sulfided phase. The formation of $\mathrm{Co}_{3} \mathrm{O}_{4}$ is generally not observed using this approach [68-73]. The 
formation of cobalt oxide on CoMo25.4/Al-B and CoMo24.8/Al-C can be attributed to the significant modifications of the pore structure upon impregnation for these two materials, since it was not observed over classical alumina and over the Al-A support that present better stability. During impregnation, $\mathrm{Co}_{2} \mathrm{Mo}_{10}$ solution exhibits a slightly acidic pH (close to 4). Under these conditions, alumina surface is positively charged (alumina point of zero charge is expected to be around 8) [74]. $\left[\mathrm{Co}_{2} \mathrm{Mo}_{10} \mathrm{O}_{38} \mathrm{H}_{4}\right]^{6-}$ anions, stable in a wide range of $\mathrm{pH}$ [75], can thus adsorb on the support, while $\mathrm{Co}^{2+}$ counter cations in solution cannot directly interact with the surface. Due to the significant decrease in pore volume of $\mathrm{Al}-\mathrm{B}$ and $\mathrm{Al}-\mathrm{C}$ supports, part of the impregnation solution can be expulsed outside of the pores. The premature precipitation of cobalt species due to limited interaction of the cobalt cations with support surface combined to decrease in pore volume can thus lead to the formation of bulk $\mathrm{Co}_{3} \mathrm{O}_{4}$ phase upon thermal treatment. Concerning molybdenum phase, good dispersion is obtained for all materials, with no evidence of the presence of $\mathrm{MoO}_{3}$ or $\mathrm{CoMoO}_{4}$ phases (that do not lead to the formation of active CoMoS phase upon activation). This is not always the case over alumina supports. Mazurelle et al. [68] observed the formation of $\mathrm{MoO}_{3}$ and $\mathrm{CoMoO}_{4}$ over conventional alumina, for equivalent $\mathrm{MoO}_{3}$ content as low as $16 \mathrm{wt} \%$. The limited surface area and pore volume $\left(200 \mathrm{~m}^{2} \cdot \mathrm{g}^{-1}\right.$ and $0.8 \mathrm{~cm}^{3} \cdot \mathrm{g}^{-1}$ - with a molybdenum surface density of $\left.4.3 \mathrm{at}_{\mathrm{Mo}} \cdot \mathrm{nm}^{-2}\right)$ displayed by $\gamma$-alumina extrudates used are at the origin of the poor Mo phase dispersion. In this last study, at the selected $16 \% \mathrm{MoO}_{3}$ loading and considering the pore volume, the impregnation solution is close to saturation. Such conditions are responsible for the precipitation of the entity during impregnation, leading to poor molybdenum phase dispersion. Over alumina synthesized in this work, the calculated Mo surface densities vary between 4.4 and $4.9 \mathrm{at}_{\mathrm{Mo}} \cdot \mathrm{nm}^{-2}$ (Table 3). These values are 
higher than the $4.3 \mathrm{at}_{\mathrm{Mo}} \cdot \mathrm{nm}^{-2}$ determined for the same precursor on conventional $\gamma$ alumina and is not far from the values of maximum densities deposited on $\gamma$-alumina using complexing agents (5.2 at $\left.\mathrm{at}_{\mathrm{Mo}} \cdot \mathrm{nm}^{-2}\right)$ while maintaining acceptable Mo dispersion [76]. Accordingly, these results demonstrate the possibility to prepare modified alumina supported catalysts with high molybdenum loading while maintaining good dispersion at high Mo densities.

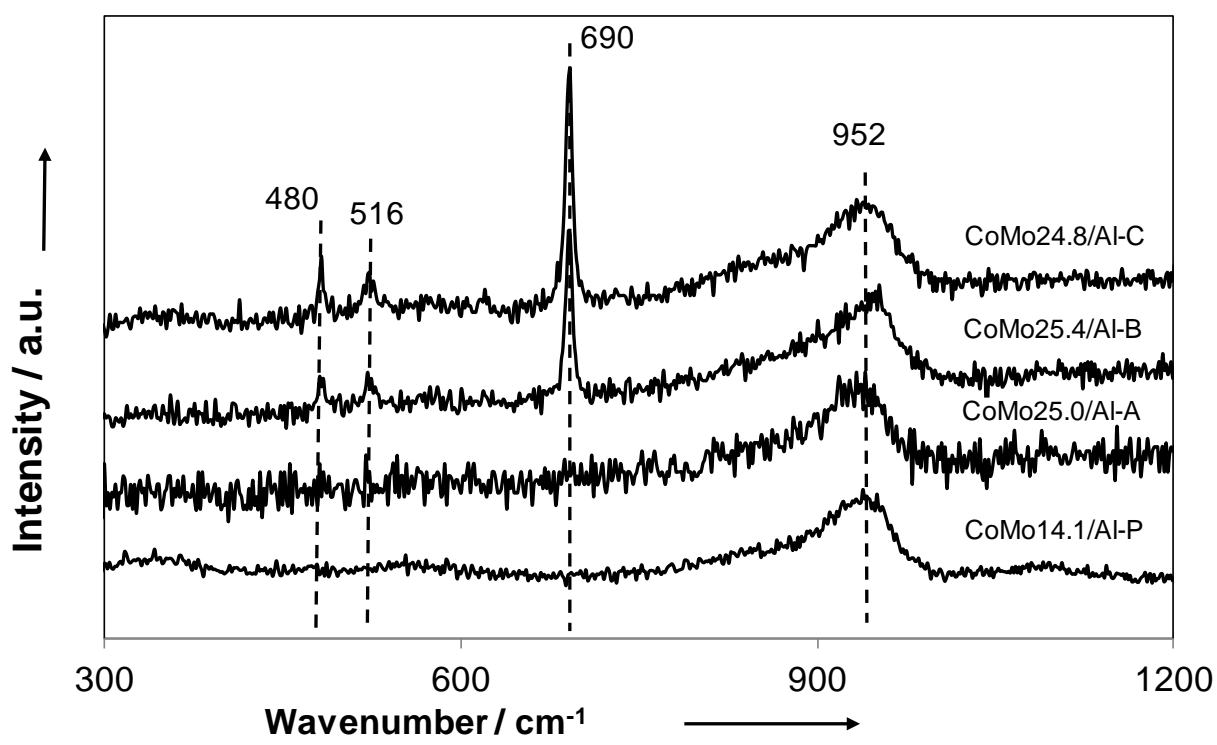

Figure 4. Raman spectra of CoMo catalysts supported on Pural Al-P, Al-A, Al-B and Al-C supports.

\subsubsection{Catalysts surface analysis.}

XPS spectra of Al2p, O1s, Mo3d, Co2p and C1s levels were recorded for the CoMo oxidic precursors. Figure SI2 shows typical Mo3d and Co2p levels spectra, presented for CoMo24.8/Al-C catalyst. For the entire series of solids, the Mo3d $\mathrm{d}_{5 / 2}$ photopeak is located at a binding energy of $233.1 \pm 0.1 \mathrm{eV}$. Such position is characteristic of Mo(VI) species. Co2p spectra show, as expected, oxidized cobalt species, with a binding energy of the $2 \mathrm{p}_{3 / 2}$ level at $781.7 \pm 0.1 \mathrm{eV}$. The analyzed solids show surface carbon contamination, as indicated in Table 4. The carbon residual contents reach values as high as $20.2 \%$ (sample CoMo24.8/Al-C) and are in all case above $10 \%$. 
This surface carbon content is mainly attributed to contamination, but on these alumina, a fraction of residual carbon can originate from residues issued from the thermal decomposition of the triblock copolymer used as porogen.

Values of atomic surface ratios are gathered in Table 4, together with the theoretical bulk ratios. All modified alumina derived catalysts present $\mathrm{n}_{\mathrm{Mo}} / \mathrm{n}_{\mathrm{Al}}$ ratios determined by XPS that are similar $(0.15 \pm 0.01)$. This value is slightly higher than the theoretical bulk ratio, indicating a satisfying dispersion of the molybdenum species on the alumina surface, as expected from the Raman results. Similar values of theoretical and experimental data are obtained on the Pural based catalyst for the $\mathrm{n}_{\mathrm{Mo}} / \mathrm{n}_{\mathrm{Al}}$ and also for $\mathrm{n}_{\mathrm{Co}} / \mathrm{n}_{\mathrm{Al}}$ ratios, while experimental $\mathrm{n}_{\mathrm{Co}} / \mathrm{n}_{\mathrm{Al}}$ is lower than the bulk ratio in the case of the materials prepared over the $\mathrm{Al}-\mathrm{B}$ and $\mathrm{Al}-\mathrm{C}$ supports. For CoMo25.0/Al-A, the experimental $\mathrm{n}_{\mathrm{Co}} / \mathrm{n}_{\mathrm{Al}}$ is only slightly higher than the theoretical bulk ratio. These results confirm the conclusions drawn from Raman analysis. Indeed, as bulk $\mathrm{Co}_{3} \mathrm{O}_{4}$ phase was not detected by Raman over CoMo25.0/Al-A, all cobalt atoms can be considered as observable by XPS, including those possibly located in tetrahedral sites of $\mathrm{CoAl}_{2} \mathrm{O}_{4}$ phase [66,77]. For the CoMo25.4/Al-B and CoMo24.8/Al-C materials, Raman analysis evidenced the formation of $\mathrm{Co}_{3} \mathrm{O}_{4}$ phase and the measured difference between the $\mathrm{n}_{\mathrm{Co}} / \mathrm{n}_{\mathrm{Al}}\left(\right.$ th) and $\mathrm{n}_{\mathrm{Co}} / \mathrm{n}_{\mathrm{Al}}$ (XPS) ratios, even limited, supports this observation as less Co atoms are then visible by XPS.

Table 4. $\mathrm{n}_{\mathrm{Mo}} / \mathrm{n}_{\mathrm{Al}}, \mathrm{n}_{\mathrm{Co}} / \mathrm{n}_{\mathrm{Al}}$ and $\mathrm{n}_{\mathrm{Co}} / \mathrm{n}_{\mathrm{Mo}}$ atomic ratios. (th) theoretical values calculated from material composition; (XPS) experimental values issued from XPS analysis.

\begin{tabular}{|c|c|c|c|c|c|c|}
\hline Sample & $\begin{array}{c}\mathrm{n}_{\mathrm{Mo}} / \mathrm{n}_{\mathrm{Al}} \\
\text { (th) }\end{array}$ & $\begin{array}{c}\mathrm{n}_{\mathrm{Mo}} / \mathrm{n}_{\mathrm{Al}} \\
\text { (XPS) }\end{array}$ & $\begin{array}{c}\mathrm{n}_{\mathrm{Co}} / \mathrm{n}_{\mathrm{Al}} \\
\text { (th) }\end{array}$ & $\begin{array}{c}\mathrm{n}_{\mathrm{Co}} / \mathrm{n}_{\mathrm{Al}} \\
\text { (XPS) }\end{array}$ & $\begin{array}{c}\mathrm{n}_{\mathrm{Co}} / \mathrm{n}_{\mathrm{Mo}} \\
(\mathrm{XPS})\end{array}$ & $\begin{array}{c}\mathrm{C}_{1 \mathrm{~s}} \\
/ \%\end{array}$ \\
\hline CoMo25.0/Al-A & 0.13 & 0.15 & 0.065 & 0.073 & 0.51 & 10.0 \\
\hline CoMo25.4/Al-B & 0.13 & 0.14 & 0.066 & 0.053 & 0.39 & 12.1 \\
\hline
\end{tabular}




\begin{tabular}{|c|c|c|c|c|c|c|}
\hline CoMo24.8/Al-C & 0.13 & 0.16 & 0.064 & 0.056 & 0.36 & 20.2 \\
\hline CoMo14.1/Al-P & 0.06 & 0.05 & 0.03 & 0.03 & 0.44 & 12.9 \\
\hline
\end{tabular}

\subsection{Catalytic properties in thiophene HDS}

Table 5 presents the catalytic performance obtained in thiophene HDS for the series of solids prepared with modified alumina. The results show a wide variation in reaction rate, from 122.5 and $186.1 \mathrm{~L} \cdot \mathrm{h}^{-1} \cdot \mathrm{kg}^{-1}$ depending on the support used. The order of activity per mass unit is as follows:

CoMo24.8/Al-C>CoMo25.4/Al-B > CoMo25.0/Al-A

Activity measured for the three catalysts prepared over the modified alumina varies by a factor $\sim 1.5$, with in all cases molybdenum initially in a well dispersed phase with no loss in bulk unsulfidable phase such as $\mathrm{MoO}_{3}$ or $\mathrm{CoMoO}_{4}$.

Table 5. Reaction rates (per mass of catalyst and per mole of Mo) of the synthesized materials for thiophene HDS reaction at $300^{\circ} \mathrm{C}$.

\begin{tabular}{|c|c|c|}
\hline Sample & $\begin{array}{c}\text { Reaction rate } \\
/ \mathrm{L}^{-1} \mathrm{~h}^{-1}\end{array}$ & $\begin{array}{c}\text { Normalized reaction rate } \\
/ \mathrm{L}^{-1} \mathrm{~h}^{-1} \cdot \mathrm{mol}_{\mathrm{Mo}}{ }^{-1}\end{array}$ \\
\hline CoMo25.0/Al-A & 122.5 & 70.5 \\
\hline CoMo25.4/Al-B & 147.1 & 83.4 \\
\hline CoMo24.8/Al-C & 186.1 & 108.1 \\
\hline
\end{tabular}

The presence of $\mathrm{Co}_{3} \mathrm{O}_{4}$ has been evidenced on the two most active materials (and especially on the most efficient one CoMo24.8/Al-C). The loss of a fraction of the initial cobalt in a poorly dispersed bulk oxide phase (that will not incorporate the 
CoMos active phase) does not seem to be detrimental to the material catalytic performance.

On CoMo catalysts prepared on commercial stable alumina, it is well known that the $\mathrm{Co} / \mathrm{Mo}$ ratio in the oxidic form of the solids must be comprised between 0.4 and 0.5 to ensure enough Co atoms to promote molybdenum disulfide slabs [69]. Indeed upon preparation a loss of cobalt is always evidenced at the different steps of the catalyst preparation especially during the drying and calcination steps [78]. During these thermal treatments a more or less important fraction of cobalt migrates inside the alumina lattice to form a pseudo $\mathrm{CoAl}_{2} \mathrm{O}_{4}$ type species and thus cannot participate to the formation of the CoMoS phase [77]. This is probably the case on Al-A support, which textural properties do not evolve upon impregnation.

On Al-B and Al-C supports, the low stability during impregnation, and more precisely the pore collapse, induces a rearrangement of the porosity during the impregnation-drying sequence which leads to precipitation of cobalt species giving $\mathrm{Co}_{3} \mathrm{O}_{4}$ after calcination. The precipitation of these cobalt species probably limits the interaction of Co with the support and thus the migration of cobalt inside the alumina lattice. Only the cobalt in the $\mathrm{Co}_{3} \mathrm{O}_{4}$ phase is thus lost for promotion.

We can then propose that upon impregnation of the various supports that we use, either the support is stable (Al-A) and some Co is lost by formation of $\mathrm{CoAl}_{2} \mathrm{O}_{4}$ type species, either the support is not stable (Al-B and Al-C) and Co is lost by formation of $\mathrm{Co}_{3} \mathrm{O}_{4}$, insuring in all cases enough available Co for efficient promotion.

XPS results show different carbon content in the prepared materials (Table 4). The most active catalyst (CoMo24.8/Al-C) contains the highest carbon surface content (20\%), while comparable carbon content were measured for the other less active solids (10-12\%). The influence of carbon on the activity of CoMo catalysts has been widely 
studied, either when used as support or when a precursor of $C$ is deposited on the support. The presence of carbon is reported to induce: (i) different sulfidation degrees of Co and Mo and (ii) different structures and/or morphologies for the generated active phase $[79,80]$. Different sulfidation degrees of Mo and Co may obviously lead to more or less promoted and dispersed active phases [81]. Moreover heat generated during the sulfidation reaction can be partially absorbed by these residues, resulting in different crystallite growth than over carbon free support [82], with positive effects on activity for HDS reactions. High HDS activities can be obtained over carbon supported Co(Ni)Mo-S active phase [84-86], with possible formation, during sulfidation, of active carbide phases [87]. Consequently, impact of carbon on final properties of prepared materials cannot be excluded.

These results in thiophene HDS thus show the possibility to produce efficient highly loaded catalysts, where good dispersion of molybdenum is preserved.

\subsection{Characterization and evaluation in SRGO HDS of the CoMo-supported sulfided catalysts CoMo24.8/Al-C and CoMo14.1/Al-P.}

In order to confirm the potential of the developed solids in conditions close to the industrial ones, the most efficient catalyst CoMo24.8/Al-C was selected for evaluation in the HDS of SRGO, its performance being compared to that of the commercial Pural based material. Characterization of the active phase after sulfidation in liquid phase was also undertaken to better understand the catalytic behavior.

\subsubsection{Morphology of the active phase for CoMo24.8/Al-C and CoMo14.1/Al-P catalysts.}

Representative TEM images of CoMo24.8/Al-C and CoMo14.1/Al-P catalysts sulfided in liquid phase are shown in Fig. 5, exhibiting the typical structure of the layered $\mathrm{MoS}_{2}$ phase. 
By statistical analysis of the images, the distribution in slab length and stacking of the $\mathrm{MoS}_{2}$ slabs were obtained and appeared to be similar on both solids, with respective average slab length of 2.7 and $2.5 \mathrm{~nm}$ and average stacking of 1.6 and 1.4 for CoMo24.8/Al-C and CoMo14.1/Al-P catalysts respectively. Morphology of the active phase is thus similar on both catalysts despite their difference in loading.
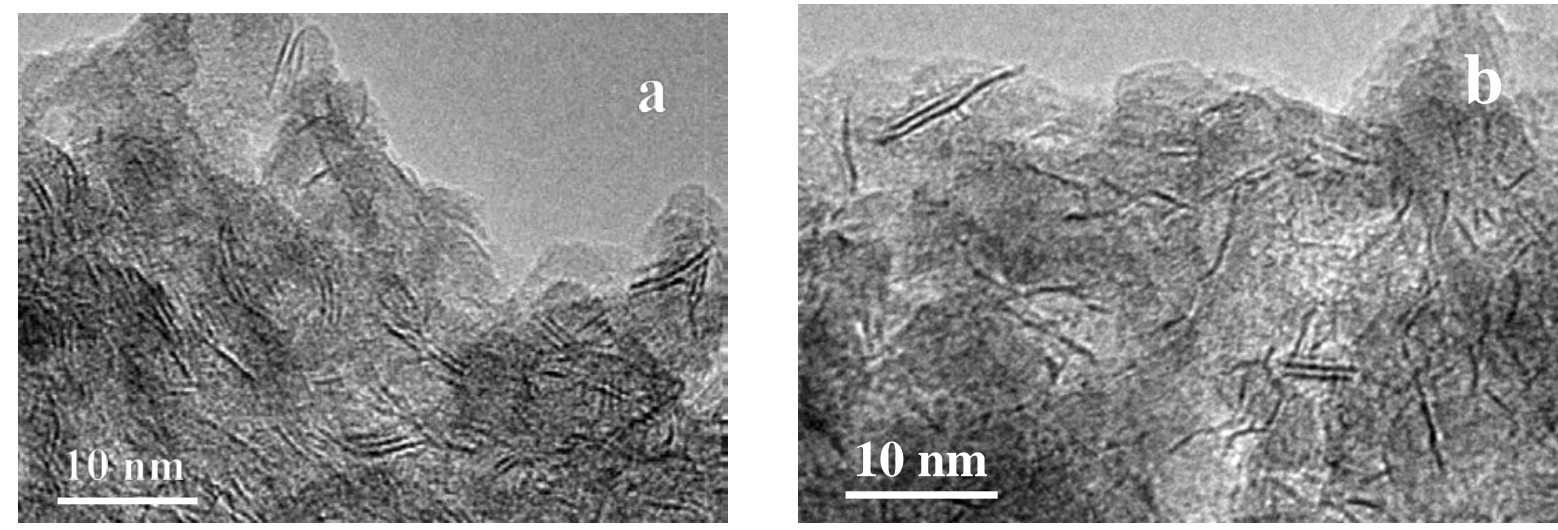

Figure 5. HRTEM images of CoMo24.8/Al-C (a) and CoMo14.1/Al-P (b) sulfided in liquid phase.

\subsubsection{XPS analysis of the sulfided catalysts CoMo24.8/Al-C and CoMo14.1/Al-P.}

XPS spectra of the Mo3d and Co2p levels (Figure SI 3) were recorded for CoMo24.8/Al-C and CoMo14.1/Al-P sulfided catalysts.

Mo spectra (Fig SI3a) exhibited three well-known contributions attributed to $\mathrm{Mo}^{\mathrm{VI}}$ oxide $\left(\mathrm{Mo3d}_{5 / 2} \mathrm{BE}=232.6 \mathrm{eV}\right), \mathrm{Mo}^{\mathrm{V}}$ oxysulfide $\left(\mathrm{Mo3d}_{5 / 2} \mathrm{BE}=230.5 \mathrm{eV}\right)$ and $\mathrm{Mo}^{\mathrm{IV}}$ sulfide $\left(\mathrm{Mo3d}_{5 / 2} \mathrm{BE}=229.0 \mathrm{eV}\right)$. In Co spectra (Fig SI3b), the three identified contributions correspond to $\mathrm{Co}$ in oxidic environment $\left(\mathrm{Co} 2 \mathrm{p}_{3 / 2} \mathrm{BE}=781.5 \mathrm{eV}\right)$, Co in sulfided environment $\left(\mathrm{Co} 2 \mathrm{p}_{3 / 2} \mathrm{BE}=778.2 \mathrm{eV}\right)$ ad $\mathrm{Co}$ in the CoMoS phase $\left(\mathrm{Co} 2 \mathrm{p}_{3 / 2} \mathrm{BE}=779.0 \mathrm{eV}\right) . \mathrm{A}$ decomposition of the XPS Mo3d and Co2p peaks was performed in a way similar to that already described in the literature [88]. All the solids showed a satisfactory and similar sulfidation extent of molybdenum with a percentage of $\mathrm{MoS}_{2}$ phase of $74.7 \%$ for CoMo24.8/Al-C and 70.7\% for CoMo14.1/Al-P. The percentage of cobalt atoms involved in 
the CoMoS phase was calculated from the decomposition of the Co2p photopeaks and corresponded to $41.6 \%$ for CoMo24.8/Al-C and 28.9\% for CoMo14.1/Al-P. From these XPS data, and taking into account the morphological parameters of the active phase determined by TEM, it is possible to calculate the substitution degree, that is the percentage of edge and corner atoms in the molybdenum disulfide slabs substituted by cobalt atoms [89]. Similar substitution degrees were obtained on the catalysts : 0.38 and 0.42 for CoMo24.8/Al-C and CoMo14.1/Al-P respectively.

These results confirmed that the quantity of cobalt involved in the formation of the active CoMoS phase after sulfidation in the liquid phase corresponds to approximately half of the edge and corner atoms of the $\mathrm{MoS}_{2}$ slabs, as already suggested by Herry et al. [90] This also shows that only a small part of the cobalt atoms introduced during the preparation is used for promotion, thus the formation of $\mathrm{Co}_{3} \mathrm{O}_{4}$ with the excess cobalt is not detrimental to promotion.

\subsubsection{Catalytic properties in SRGO HDS}

Catalytic performance of CoMo24.8/Al-C and CoMo14.1/Al-P were evaluated in the HDS of SRGO 10000 ppmS. For both solids, the residual sulfur content in the hydrotreated product was plotted as a function of the reactor temperature, as shown in Figure 6. The modified alumina derived catalyst appears significantly more efficient than the commercial alumina supported one (per volume of catalyst and per mass of catalyst, considering their similar apparent densities), with 181 versus 415 ppmS at $350^{\circ} \mathrm{C}$ and 34 versus $100 \mathrm{ppmS}$ at $370^{\circ} \mathrm{C}$. A substantial temperature gain, which is an important parameter in industrial applications, is thus evidenced for the CoMo24.8/Al$\mathrm{C}\left(17^{\circ} \mathrm{C}\right.$ for $100 \mathrm{ppm}$ residual S). Moreover after one week of test, the performance measured again at $350^{\circ} \mathrm{C}$ was found identical to that obtained initially, showing the stability of the system. 
Characterization of the sulfided phase has shown similar morphology for the active phase together with similar substitution degree. The better performance of the CoMo24.8/Al-C can then be attributed to the higher quantity of active phase that is introduced in the reactor, due to its higher Co and Mo loading.

These results confirm the potential of highly loaded CoMoS catalysts developed in this study as support for HDS catalyst, not only for the conversion of model molecules but more interestingly also for the desulfurization of real feedstocks. From our knowledge, this is the first time that such high loading, with well dispersed active phase, is reported over alumina in HDS of SRGO under experimental conditions representative of industrial ones. Due to the high active phase loading allowed by the improved textural properties, final material presents increased HDS catalytic properties.

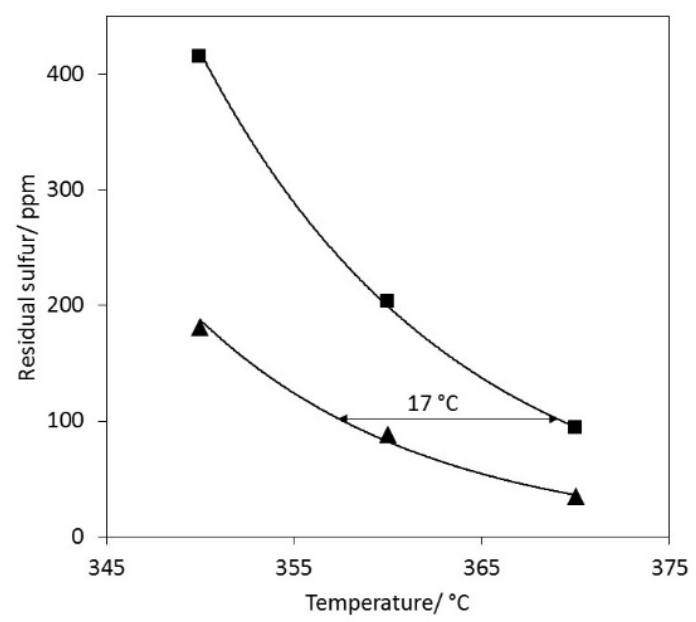

Figure 6. Catalytic performance of the CoMo24.8/Al-C ( $\mathbf{\Delta}$ ) and CoMo14.1/Al-P ( $\mathbf{\square})$ catalysts in the HDS of SRGO. Residual sulfur content in the desulfurized feed versus the temperature of the reactor.

\section{Conclusions}

Alumina porosity can be easily tuned using a post-modification approach involving the use of triblock copolymer structuring agent. Addition of porogen was performed during the peptization step, which is industrially performed prior to the alumina 
shaping. No extra step would thus be required in the industrial alumina preparation process. The amount of porogen and the acidic conditions of the peptization step were varied in this study as they are key parameters allowing to tune the final textural properties of the support. While maintaining high surface areas (close to $400 \mathrm{~m}^{2} \cdot \mathrm{g}^{-1}$ ), large porosity were thus obtained: pore volume can exceed $2 \mathrm{~cm}^{3} \cdot \mathrm{g}^{-1}$, with pore diameters that can reach $20 \mathrm{~nm}$. The role of the selected porogen, in our case the triblock copolymer P123, consists in the modification of the alumina particles agglomeration and the acidic conditions selected for the modification steps does not induce significant modification of the elementary particle size, as deduced from the preservation of almost constant surface area for all modified alumina.

The high surface areas and high pore volumes displayed by the modified alumina allowed to prepare highly loaded CoMo catalysts. Upon impregnation, slight decrease in specific surface was observed on all solids while some collapse of the porous structure was noted on solids with large pore size superior to $15 \mathrm{~nm}$. Final textural properties remained however attractive, with specific surface areas and pore volumes higher than the values encountered for classical alumina support. On all solids, satisfying dispersion of molybdenum species is obtained with no formation of undesirable bulk species as usually observed at high loading. On the solids presenting pore collapse, the unusual presence of $\mathrm{Co}_{3} \mathrm{O}_{4}$ was observed, which was explained by the precipitation of cobalt species due to limited interaction of the cobalt cations with support surface combined to decrease in pore volume. It is however suggested that in this case, the formation of $\mathrm{CoAl}_{2} \mathrm{O}_{4}$ type species is not favoured, the amount of cobalt available for promotion remaining thus sufficient.

Catalysts displayed activities in the HDS of thiophene varying by a factor of 1.5 and the performance of the most efficient solid of the series was evaluated in the HDS of 
SRGO under industrial conditions. It was found significantly more active than a CoMo catalyst prepared on a commercial alumina with similar dMo (temperature gain of $17^{\circ} \mathrm{C}$ at $100 \mathrm{ppm}$ residual sulfur content), with a preserved activity after one week of testing. The two solids presented similar morphologies of the active phase as well as similar substitution degree as determined from XPS and TEM characterization of the sulfided phase. The higher performance of the mesoporous alumina supported catalyst can then be attributed to its high Mo and Co loading. This work thus highlights the interest of developing alumina supports with improved textural properties in order to produce well-dispersed highly loaded catalysts with enhanced HDS ability.

\section{Acknowledgements}

This work was supported by the Equatorian Government and IFPEN. Chevreul Institute (FR 2638), Ministère de l’Enseignement Supérieur et de la Recherche, Région Nord - Pas de Calais and FEDER are acknowledged for supporting and funding partially this work (XPS, TEM). M. Trentesaux is acknowledged for XPS analysis support.

\section{References}

1 Directive 2009/30/EC of the European Parliament.

2 H.Topsøe, B. S. Clausen, F. E. Massoth, Hydrotreating Catalysis, Springer, Berlin, 1996.

3 R. Prins, V. H. J. De Beer, G. A. Somorjai, Catal. Rev.: Sci. Eng. 32 (1989) 1-41.

4 E. J. M. Hensen, Y. van der Meer, J. A. R. van Veen, J. W. Niemantsverdriet, Appl. Catal. A 322 (2007) 16-32.

5 J. F. Lepage, Catalyse de Contact: conception, préparation et mise en œuvre des catalyseurs industriels, TECHNIP, Paris, 1978. 
6 S. Dzwigaj, C. Louis, M. Breysse, M. Cattenot, V. Bellière, C. Geantet, M. Vrinat, P. Blanchard, E. Payen, S. Inoue, H. Kudo, Y. Yoshimura, Appl. Catal. B 41 (2003)181-191.

7 C. Lamonier, D. Soogund, J. Mazurelle, P. Blanchard, D. Guillaume, E. Payen, Stud. Surf. Sci. Catal. 162 (2006) 713-720.

8 I. Merdrignac, D. Espinat, Oil and Gas Science and Technology 62 (2007) 7-32.

9 C. T. Kresge, M. E. Leonowicz, W. J. Roth, J. C. Vartuli, J. S. Beck, Nature 359 (1992) 710712.

10 D. Trong On, D. Desplantier-Giscard, C. Danumah, S. Kaliaguine, Appl. Catal. A 253 (2003) 543-602.

11 D. Zhao, Q. Huo, J. Feng, B. F. Chmelka, G. D. Stucky, J. Am. Chem. Soc. 120 (1998) 60246036.

12 D. Zhao, J. Feng, Q. Huo, N. Melosh, G. H. Fredrickson, B. F. Chmelka, G. D. Stucky, Science 279 (1998) 548-552.

13 U Ciesla, F. Schuth, Micro. Meso. Mater. 27 (1999) 131-149.

14 F. Schuth, Chem. Mater. 13 (2001) 3184-3195.

15 A. Taguchi, F. Schuth, Micro. Meso. Mater. 77 (2005) 1-45.

16 Y. Ren, Z. Ma, P. G. Bruce, Chem. Soc. Rev. 41 (2012) 4909-4927.

17 D. Gu, F. Schuth, Chem. Soc. Rev. 43 (2014) 313-344.

18 S. A. Bagshaw, T. J. Pinnavaia, Angew. Chem. 35 (1996) 1102-1105.

19 F. Vaudry, S. Khodabandeh, M. E. Davis, Chem. Mater. 8 (1996) 1451-1464.

20 S. Valange, J.-L. Guth, F. Kolenda, S. Lacombe, Z. Gabelica, Micro. Meso. Mater. 35-36 (2000) 597-607.

21 C. Márquez-Alvarez, N. Žilková, J. Pérez-Pariente, J. Čejka, Catal. Rev. Sci. Eng. 50 (2008) 222-286.

22 S. Royer, C. Leroux, A. Chaumonnot, R. Revel, S. Morin, L. Rouleau, Stud. Surf. Sci. Catal. 165 (2007) 231-234. 
23 W. El-Nadjar, M. Bonne, E. Trela, L. Rouleau, A. Mino, S. Hocine, E. Payen, C. Lancelot, C. Lamonier, P. Blanchard, X. Courtois, F. Can, D. Duprez, S. Royer, Micro. Meso. Mater. 158 (2012) 88-98.

24 A. Sayari, Y. Yang, M. Kruk, M. Jaroniec, J. Phys. Chem. B 103 (1999) 3651-3658.

25 A. Sayari, Angew. Chem. 39 (2000) 2920-2922.

26 X. Cui, J.-H. Ahn, W.-C. Zin, W.-J. Cho, C.-S. Ha, Stud. Surf. Sci. Catal. 146 (2003) 117-120.

27 L. Cao, T. Man, M. Kruk, Chem. Mater. 21 (2009) 1144-1153.

28 J. Čejka, Appl. Catal. A 254 (2003) 327-338.

29 M. Yada, M. Machida, T. Kijima, Chem. Commun. (1996) 769-770.

30 K. Niesz, P. Yang, G. A. Somorjai, Chem. Commun. (2005) 1986-1987.

31 Q. Yuan, A.-X. Yin, C. Luo, L.-D. Sun, Y.-W. Zhang, W.-T. Duan, H.-C. Liu, C.-H. Yan, J. Am. Chem. Soc. 130 (2008) 3465-3472.

32 S. M. Morris, P. F. Fluvio, M. Jaroniec, J. Am. Chem. Soc. 130 (2008) 15210-15216.

33 K. L. Materna, S. M. Grant, M. Jaroniec, ACS Appl. Mater. Interfaces 4 (2012) 3738-3744.

34 W. Cai, J. Yu, M. Jaroniec, J. Mater. Chem. 21 (2011) 9066-9072.

35 J.-P. Dacquin, J. Dhainaut, D. Duprez, S. Royer, A. F. Lee, K. Wilson, J. Am. Chem. Soc. 131 (2009) 12896-12897.

36 L. Vradman, M. V. Landau, M. Herskowitz, V. Ezersky, M. Taliander, S. Nikitenko, Y. Koltypin, A. Gedanken, J. Catal. 213 (2003) 163-175.

37 L. Lizama, T. Klimova, Appl. Catal. B 82 (2008) 139-150.

38 R. Huirache-Acuna, B. Pawelec, E. Rivera-Munoz, R. Nava, J. Espino, J. L. G. Fierro, Appl. Catal. B 92 (2009) 168-184.

39 V. La Parola, B. Dragoi, A. Ungureanu, E. Dumitriu, A. M. Vanezia, Appl. Catal. A 386 (2010) 43-50.

40 P. E. Boahene, K. K. Soni, A. K. Dalai, J. Adjaye, Appl. Catal. A 402 (2011) 31-40.

41 T. Chiranjeevi, G. Muthu Kumaran, G. Murali Dhar, Pet. Sci. Technol. 26 (2008) 690-703.

42 M. Hussain, S.-K. Song, J.-H. Lee, S.-K. Ihm, Ind. Eng. Chem. Res. 45 (2006) 536-543. 
43 R. Nava, A. Infantes-Molina, P. Castao, R. Guil-Lopez, B. Pawelec, Fuel 90 (2011) 27262737.

44 T. A. Zepeda, T. Halachev, B. Pawelec, R. Nava, T. Klimova, G. A. Fuentes, J. L. G. Fierro, Catal. Commun. 7 (2006) 33-41.

45 K. Soni, K. C. Mouli, A. K. Dalai, J. Adjaye, Catal. Lett. 136 (2010) 116-125.

46 M. T. Nguyen Dinh, P. Rajbhandari, C. Lancelot, P. Blanchard, C. Lamonier, M. Bonne, S. Royer, F. Dumeignil, E. Payen, ChemCatChem 6 (2014) 328-338.

47 J. Čejka, N. Zilková, L. Kaluža, M. Zdražil, Stud. Surf. Sci. Catal. 141 (2002) 243-250.

48 L. Kaluža, M. Zdražil, N. Žilková, J. Čejka, Catal. Comm. 3 (2002) 151-157.

49 R. W. Hicks, N. B. Castagnola, Z. Zhang, T. J. Pinnavaia, C. L. Marshall, Appl. Catal. A 254 (2003) 311-317.

50 N. Bejenaru, C. Lancelot, P. Blanchard, C. Lamonier, L. Rouleau, E. Payen, F. Dumeignil, S. Royer, Chem. Mater. 21 (2009) 522-533.

51 X.-M. Liu, H.-X. Xue, X. Li, Z.-F. Yan, Catal. Today 158 (2010) 446-451.

52 X. Liu, X. Li, Z. Yan, Appl. Catal. B 121-122 (2012) 50-56.

53 S. Badoga, R. V. Sharma, A. K. Dalai, J. Adjaye, Appl. Catal. A 489 (2015) 86-97.

54 Q. Liu, A. Wang, X. Wang, P. Gao, T. Zhang, Micro. Meso. Mat. 111 (2008) 323-333.

55 P. F. Fulvio, R. I. Brosey, M. Jaroniec, ACS Appl. Mater. Interfaces 2 (2010) 588-593.

56 F. Karouia, M. Boualleg, M. Digne, P. Alphonse, Powder Technology, Elsevier, 2013, vol. 237, pp 602-609.

57 Y. Zheng, J. Song, X. Xu, M. He, Q. Wang, L. Yan, Ind. Eng. Chem. Res. 53 (2014) 1002910034.

58 C. Martin, C. Lamonier, M. Fournier, O. Mentré, V. Harlé, D. Guillaume, E. Payen, Chem. Mater. 17 (2005) 4438-4448.

59 Z. Zhang, T. J. Pinnavaia, J. Am. Chem. Soc. 124 (2002) 12294-12301.

60 Z. Zhang, T. J. Pinnavaia, Angew. Chem. 47 (2008) 7501-7504.

61 S. Cabrera, J. E. Haskouri, J. Alamo, A. Beltrán, D. Beltrân, S. Mendioroz, M. Dolores Marcos, P. Amorôs, Advanced Materials 11 (1999) 379-381. 
62 D. P. Debecker, M. Stoyanova, U. Rodemerck, P. Eloy, A. Léonard, B.-L. Su, E. M. Gaigneaux, J. Phys. Chem. C 114 (2010) 18664-18673.

63 L. Kaluža, D. Gulková, O. Šolcová, N. Žilková, J. Čejka, Appl. Catal. A 351 (2008) 93-101.

64 D. Gulková, L. Kaluža, Z. Vít, M. Zdražil, Catal. Com. 7 (2006) 276-280.

65 E. Payen, J. Grimblot, J. C. Lavalley, M. Daturi, F. Maugé, Handbook of Vibrational Spectroscopy, John Wiley \& Sons, 2006.

66 P. Blanchard, C. Lamonier, A. Griboval, E. Payen, Appl. Catal. A 322 (2007) 33-45.

67 C.-W. Tang, C.-B. Wang, S.-H. Chien, Thermochim. Acta 473 (2008) 68-73.

68 J. Mazurelle, C. Lamonier, C. Lancelot, E. Payen, C. Pichon, D. Guillaume, Catal. Today 130 (2008) 41-49.

69 C. Lamonier, C. Martin, J. Mazurelle, V. Harlé, D. Guillaume, E. Payen, Appl. Catal. B 70 (2007) 548-556.

70 C.I. Cabello, F. M. Cabrerizo, A. Alvarez, H. J. Thomas, J. Mol. Catal. A 166 (2002) 89-100.

71 P. A. Nikulshin, D. I. Ishutenko, A. A. Mozhaev, K.I. Maslakov, A. A. Pimerzin, J. Catal. 312 (2014) 152-169.

72 P. A. Nikulshin, A. V. Mozhaev, K. I. Maslakov, A. A. Pimerzin, V. M. Kogan, Appl. Catal. B 158-159 (2014) 161-174.

73 A. A. Pimerzin, P. A. Nikulshin, A. V. Mozhaev, A. A. Pimerzin, A. I. Lyashenko, Appl. Catal. B 168-169 (2015) 396-407.

74 P. Euzen, P. Raybaud, X. Krokidis, H. Toulhoat, J.-L. Le Loarer, J. P. Jolivet, C. Froidefond, Alumina, Handbook of Porous Solids, Wiley-VCH, Weinheim, 2002, 1591-1677.

75 J. Moreau, O. Delpoux, E. Devers, M. Digne, S. Loridant, J Phys Chem A 116 (2012) 263270.

76 P. Blanchard, E. Payen, J. Grimblot, O. Poulet, R. Loutaty, Stud. Surf. Sci. Catal. 106 (1997) 211-223.

77 J. A. R. van Veen, E. Gerkema, A. M. van der Kraan, P. A. J. M. Hendriks, H. Beens, J. Catal. 133 (1992) 112-123. 
78 P. Blanchard, C. Mauchaussé, E. Payen, J. Grimblot, Stud. Surf. Sci. Catal. 91 (1995) 10371049.

79 F. Labruyère, P. Dufresne, M. Lacroix, M. Breysse, Catal. Today 43 (1998) 111-116.

80 J. Vangestel, J. Leglise, J. C. Duchet, J. Catal. 145 (1994) 429-436.

81 L. Coulier, V. H. J. De Beer, J. A. R .Van Veen, J. W. Niemantsverdriet, J. Catal. 197 (2001) 26-33.

82 C. Glasson, C. Geantet, M. Lacroix, F. Labruyere, P. Dufresne, J. Catal. 212 (2002) 76-85.

83 M. Kouzu, Y. Kuriki, F. Hamdy, K. Sakanishi, Y. Sugimoto, I. Saito, Appl. Catal. A 265 (2004) 61-67.

84 L. Kaluža, M. Zdražil, Carbon 39 (2001) 2023-2034.

85 S. J. Moon, S. K. Ihm, Korean J. Chem. Eng. 11 (1994) 111-118.

86 E. J. M. Hensen, M. J. Vissenberg, V. H. J. de Beer, J. A. R. van Veen, R. A. van Santen, J. Catal. 163 (1996) 429-435.

87 R. R. Chianelli, G. Berhault, Catal.Today 53 (1999) 357-366.

88 N. Frizi, P. Blanchard, E. Payen, P. Baranek, C. Lancelot, M. Rebeilleau, C. Dupuy, J.P. Dath, Catal. Today 130 (2008) 32-40.

89 PhD Andres Mino, University of Lille, 2012.

90 S. Herry, O. Chassard, P. Blanchard, N. Frizi, P. Baranek, C. Lancelot, E. Payen, S. van Donk, J. P. Dath, M. Rebeilleau, Stud. Surf. Sci. Catal. 175 (2010) 567-570. 


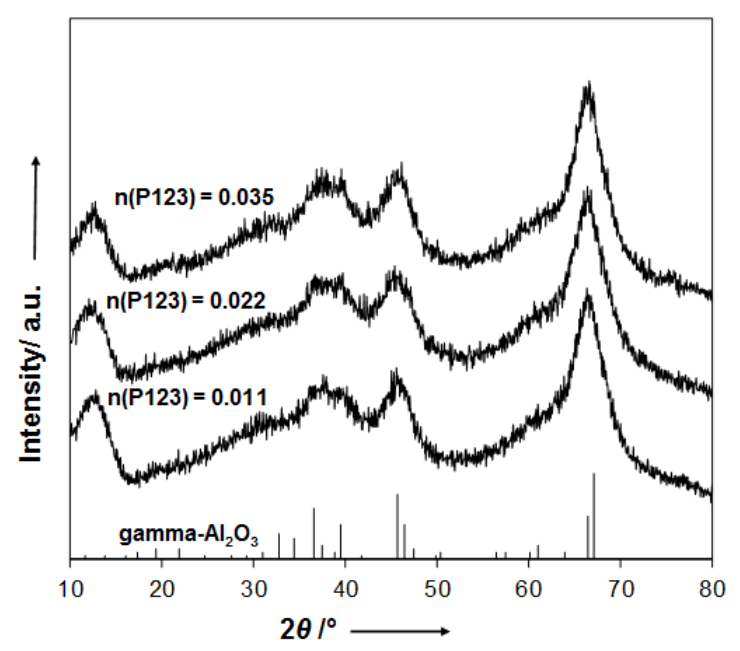

Figure SI 1. XRD diffractograms of alumina supports obtained at different P123 contents and calcined at $550^{\circ} \mathrm{C} ; \mathrm{n}(\mathrm{P} 123)=0.011,0.022,0.035 \mathrm{~mol}$.
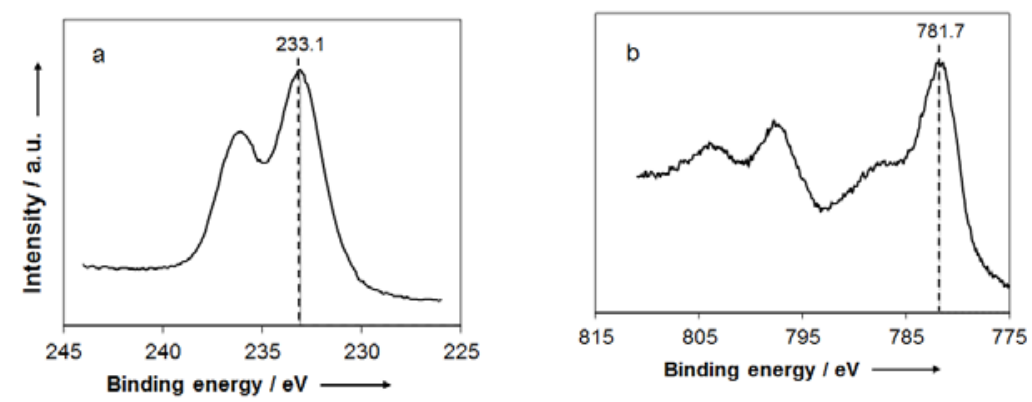

Figure SI 2. XPS spectra of Mo3d (a) and Co2p (b) levels for CoMo24.8/Al-C.
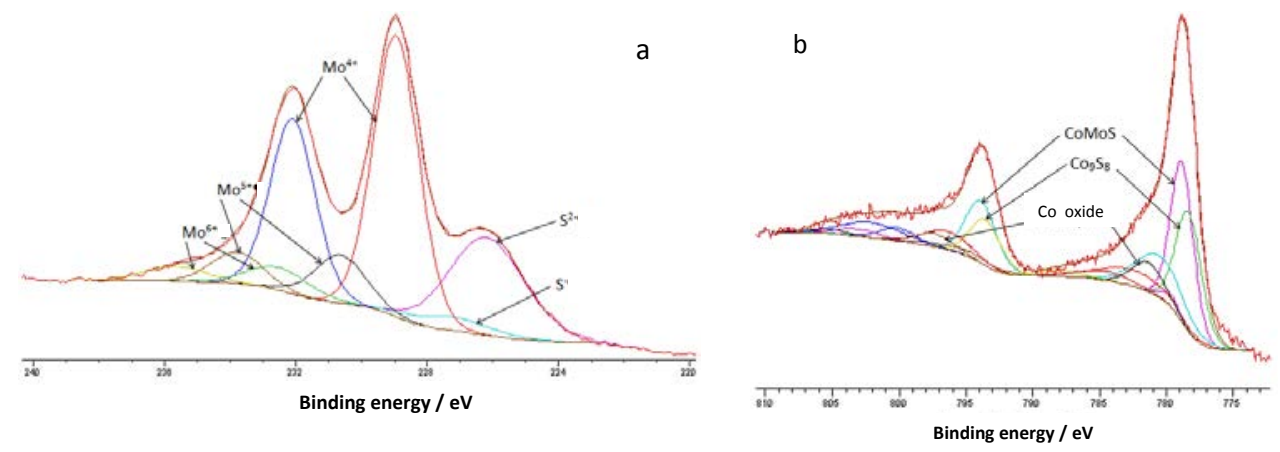

Figure SI 3. XPS spectra of Mo3d (a) and Co2p (b) levels for sulfided CoMo24.8/Al-C. 